\title{
Iron Mineralogy in the Chinese Deserts and Mongolian Gobi: Impact for the Biogeochemical Cycle
}

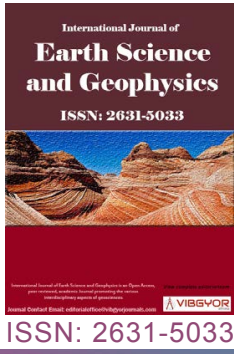

\section{Tong $\mathrm{He}^{*}$}

School of Geographic Sciences, Nanjing University of Information Science and Technology, Nanjing, China

\begin{abstract}
Deserts are the major source of the dust greatly impact the biogeochemical cycles. However, quantitatively evaluating iron forms in the dust source areas is still a challenge due to large uncertainty in the iron mineralogy. Here we investigate iron mineralogy of 19 surface sand samples collected from seven deserts along the arid zone in North China and Mongolia. By use of a Mineral Liberation Analyzer (MLA) technique, we show that the iron mineral assemblages include a total of 38 mineral phases. In particular, chlorite and hornblende contribute $50-60 \%$ iron content of in the Chinese deserts along the metamorphic mountain belts of Northern Tibetan Plateau (NTP). The newly uplifted and strongly erosive mountain provides easily-deducible chlorite and hornblende, and filled the Chinese deserts as sediments. This region has much higher iron content relative to Mongolia Gobi. This finding suggests that the active mountain belts mentioned above are of great importance of dust input in iron. Further analyses of the iron content in particle size distribution suggest that the desert sourced dust tended to decrease the initial iron content originated from the mountain belts, considering the size reduction during the transport. Based on the spatial variation of the iron content, combined with the dust flux in each desert, we estimated the upper limit for the atmospheric iron influx. Our estimation provides a basis for assessing the marine "biological pump" effect, that causing fundamental changes in the atmospheric $\mathrm{CO}_{2}$ level.
\end{abstract}

\section{Keywords}

Chinese deserts, Iron phases, Iron provenance, Iron influx, Grain size effect

\section{Introduction}

Sand emission and dust production at deserts can explain the large amount of iron nutrients that affect global biogeochemical cycle [1]. Mineral particle is the dominant component of iron deposition into the oceans, accounts for $95 \%$ of the globally averaged atmospheric sourced iron budget [2]. A large fraction of iron loading in mineral dust is in the form of iron oxide [3,4]. Schroth, et al. [5] uses a direct synchrotron-based measurement (EXAFS) to reveal that the easily-deducible iron phases, e.g. goethite and ferrihydrite are "inherited" from the weathering of larger particles as hornblende. Journet, et al. [6] conducts acid-leaching experiments and observed that the illite (species of muscovite) contributed heavily for the easily-deducible iron. Takahashi, et al. [7] showed that, in Asian dust, Fe

*Corresponding author: Tong He, School of Geographic Sciences, Nanjing University of Information Science and Technology, Nanjing, 210093, China

Accepted: May 16, 2020; Published: May 18, 2020

Copyright: (C) $2020 \mathrm{He} \mathrm{T}$. This is an open-access article distributed under the terms of the Creative Commons Attribution License, which permits unrestricted use, distribution, and reproduction in any medium, provided the original author and source are credited.

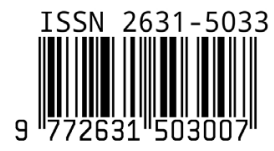

He T. Int J Earth Sci Geophys 2020, 6:034 
is mostly present in illite (muscovite) and chlorite. Lu, et al. [8] supports that the easily-deducible iron in dust is through the Fe release from the chlorite.

So, it appears that the easily-deducible iron in dust is closely linked to the candidate iron phases such as hornblende, chlorite and illite (muscovite), given that the iron oxide phases are their secondary weathering product [9]. So far, detailed measurement of the geochemical abundances for these iron phases is lacking. Most desert particles suitable for dust transport are associated with the fine particles $(<20 \mu \mathrm{m})$ [10]. On the downward trajectory, the collision of coarse-sized $(20-75 \mu \mathrm{m})$ fraction particles/aggregates result in the emission of the fine grains from the surface of larger size particles [11]. The iron mineral composition in the fine-sized fraction is inherited from the coarse-sized fraction. Thus, mineralogical iron speciation in the fine-sized and coarse-sized fractions should be investigated.

Previous geochemical studies have shown that the surface sands in these sampling areas are as- sociated with the newly uplifted mountains in High Asia [12-16]. The loose desert sediments are brought into the present desert basins directly by fluvial and glacial processes from surrounding mountain $[17,18]$. Considering a very high rate of denudation and mountain erosion in the studied source area of inland Asia $[19,20]$, it can be hypothesized that fluvial and glacial sediments from high mountains contain relatively more easily-deducible iron phases. Weathering process particularly in the nearby dried lake and river beds may also contribute iron phases $[21,22]$. The two distinct iron sources probably account for the different response in mineral composition [23]. However, due to the lack of spatially sampled dust from the potential source area, the comparison of iron provenance and the source mechanism remains unclear.

Here we use Mineral Liberation Analyzer (MLA) technique to characterize iron mineralogy of associated particles in samples collected from deserts surface sands covering the deserts in North China and the Mongolia Gobi. Estimation of the iron in-

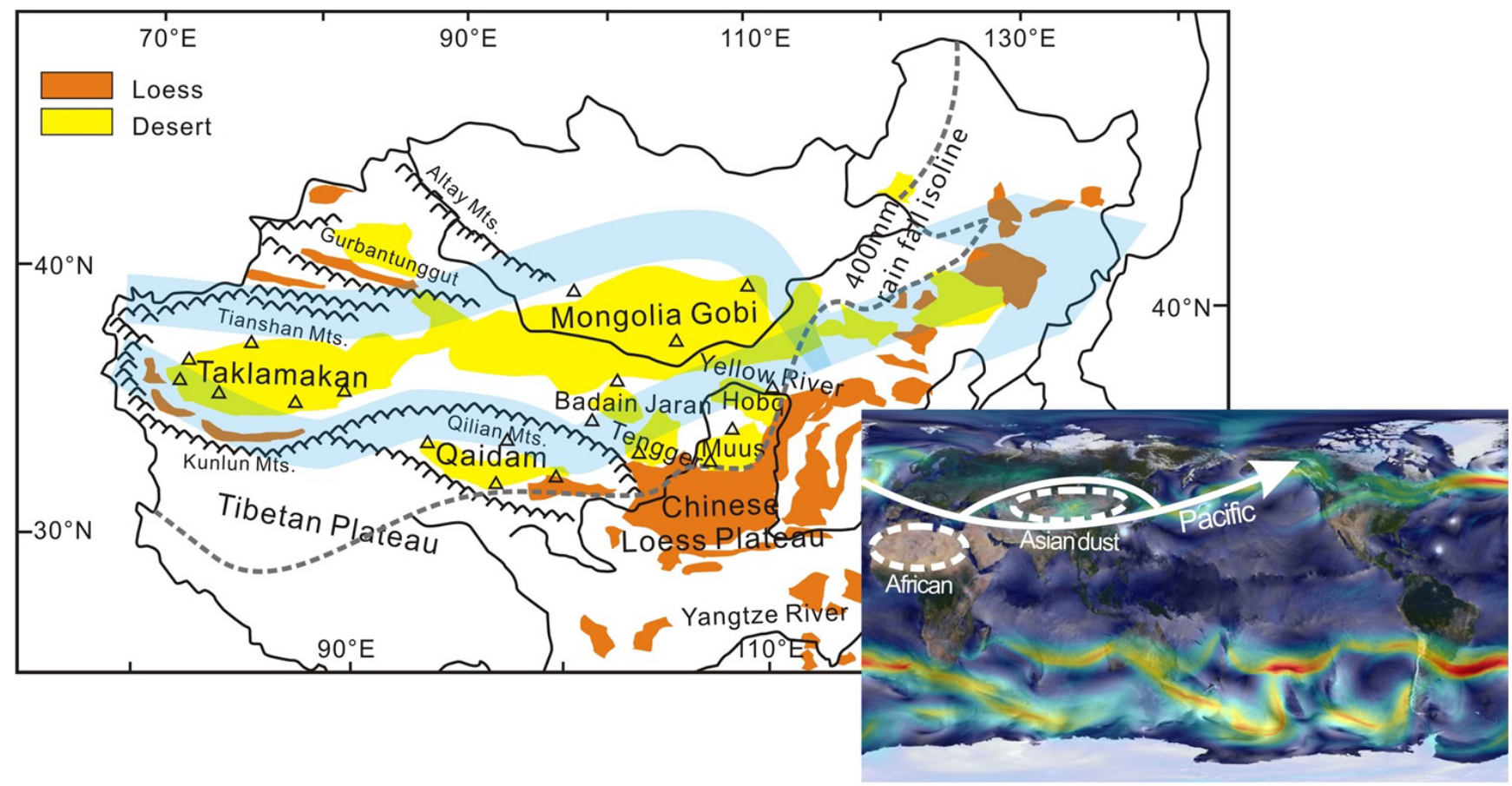

Figure 1: Map showing the extent of the Gobi and other deserts of Asian Dust provenance. Desert source mountains include the Kunlun, Qilian, Tian shan and Altyn ranges. The foreland basins for these mountains, include the Taklamakan Desert (TK), the Qaidam Desert (Qdm), the Badain Jaran Desert (BJ), the Mu Us Desert (Mu Us), the Hobq Desert ( $\mathrm{Hbq}$ ), the Tengger Desert (TGL) and the Mongolian Gobi Desert (MG). The deserts are filled with eroded fresh minerals from surrounding mountain bedrock. Sampling sites in these deserts are denoted in empty triangles. These desert materials are subjected to strong dust transport during Spring storms by westerly jet [56] (wind direction denoted with light blue arrow). The long-range transport of these easilyweathered minerals increases dust influx along their pathway, from the Chinese Loess Plateau, to Korea, Japan, the North Pacific and Greenland. The world map is sourced from NASA website [57]. 
flux became possible if present data of dust emission flux $[24,25]$ are jointly interpreted in the light of detailed iron mineralogy. Based on the geochemical abundances of the iron phases, combined with previous data of dust flux from field stations, we ultimately estimate the upper limit for the atmospheric iron influx.

\section{Material and Method}

We investigated seven deserts: Taklamakan Desert and Qaidam Desert in the inland of northwestern China, Badain Jaran Desert, Tengger Desert, Mu Us Desert and Hobq Desert in North China and Mongolia Gobi Desert (Figure 1). The Chinese deserts are located in the low lying areas of basins, and the Mongolian Gobi is on the flat tableland [26]. The Chinese deserts are mainly covered by mobile sand dunes [27], whereas the Mongolian Gobi is predominated with gravel land. The mobile dunes deserve particular attention, because dune mobili- ty has profound impacts on dust production [28]. A total of 19 surface sand samples (within the upper $20 \mathrm{~cm}$ ) were collected. The landscape descriptions were shown in Supplementary Table 1S, revealing current status of these sampling sites.

We selected the non-clay sized (> $5 \mu \mathrm{m}$ ) fractions to study mineral abundances using MLA. MLA, in combination with computer automated $X$-ray analysis, allows us to quantify iron content and its cation species in iron associated minerals as low as $0.1 \%$ [29]. A MLA-650 system is composed of a Quanta 650 SEM and dual EDAX EDS detectors. Operation conditions were $40 \mu \mathrm{A}$ probe current, 15 $\mathrm{kV}$, a magnification of $800 \mathrm{X}$ and frame resolution at $1024 \times 800$. The image brightness and contrast were calibrated with a gold pin in the standard block on the stage. The grey level of the gold in BSE image was set to about 230 and background (resin) was set to about 20. The target numbers of frames

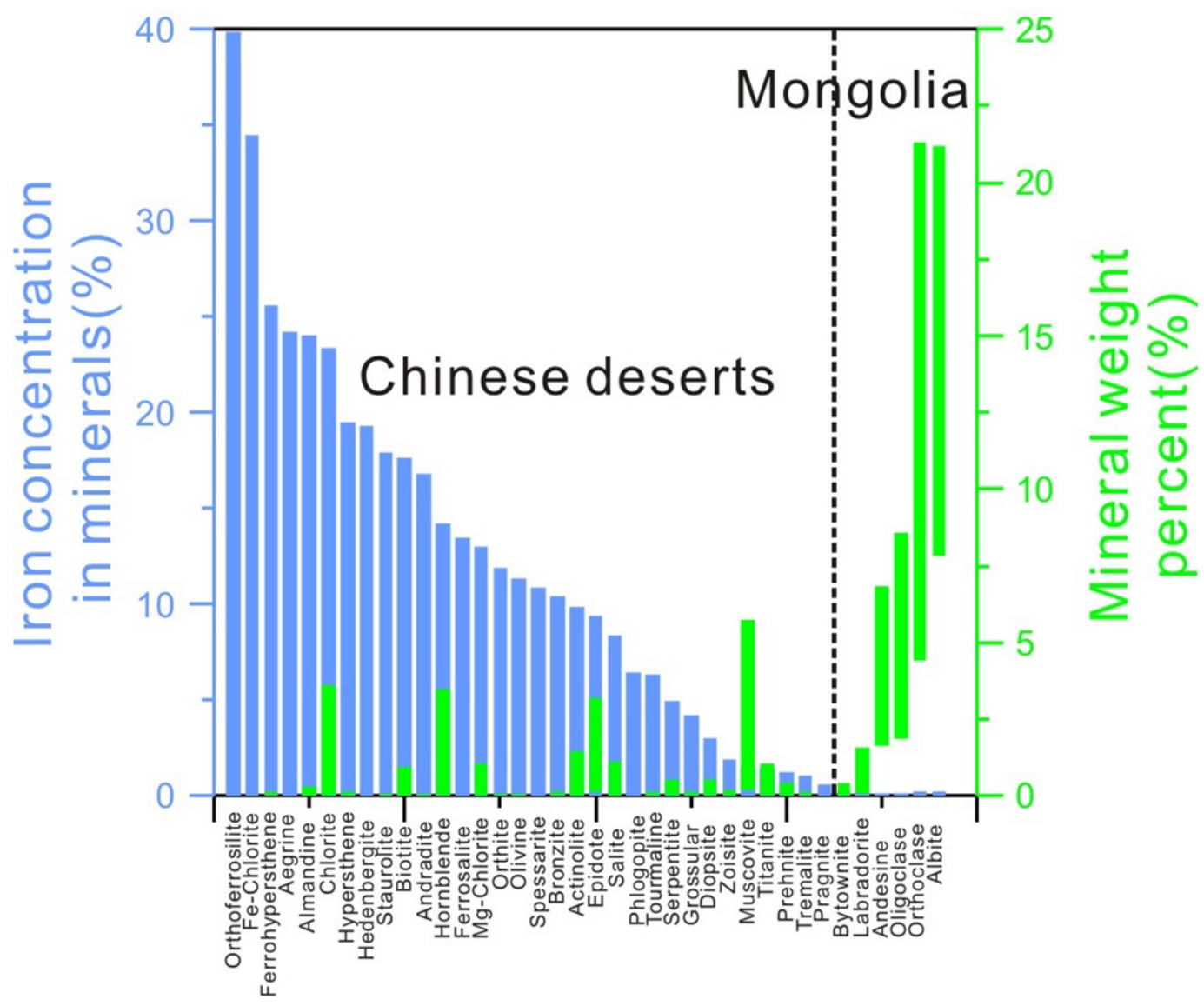

Figure 2: Iron associated silicate mineral species quantified using the MLA. We identified 38 mineral species with detectable iron content $(>0.2 \%)$. The minerals were listed in decreasing order of mineral iron concentration (blue bar). Mineral abundance (floating green bar) for feldspar group minerals (orthoclase, albite, oligoclase, andesine and labradorite) show higher mineral abundance, but low mineral iron concentration, thus less significant in iron amount. Chlorite and hornblende, dominated by Fe (II), show both high abundances (> 2\%) and evident iron concentrations (> 10\%), which are major iron associated silicates. 
and particles to be analyzed for each sample were set to 400 and 40,000 , respectively.

The area percentage data were converted using mineral density to obtain weight percent data. An iron elemental composition of each mineral is according to the standard mineralogy handbook [30]. Then iron concentration in each mineral phase was multiplied with the mineral phase abundance. The sum for all phases of iron minerals are referred as the sample's iron content, hereinafter, the "iron content".

\section{Results}

A total of 38 mineral phases obtained detectable iron (Figure 2). Most of the identified iron phases are minor in abundance $(<1 \%)$, thus, they are not important in the iron content. The primary 12 iron phases e.g. hornblende, chlorite, epidote, muscovite, biotite, salite, actinolite, almandine, $\mathrm{K}$-feldspar, andesine, oligoclase and albite account for $80-95 \%$ of the iron amount.
Hornblende and chlorite weighted $50-60 \%$ iron content in all samples from the Chinese deserts, compared with $31.6 \%$ and $7.3 \%$ in samples MG05 and MG14, respectively. Iron content in Mongolia desert partitioned heavily in phase of K-feldspar. The distinct mineralogical composition has a pronounced influence on sample's chemistry. As the standard chemical composition has shown [30], chlorite and hornblende mineral have high level of $\mathrm{Fe} / \mathrm{Si}$ ratios at 1.99 and 0.70 , respectively. K-feldspar has low value of $\mathrm{Fe} / \mathrm{Si}$ ratios at $\sim 0.01$. Therefore, the samples from the Chinese deserts are consistently high in $\mathrm{Fe} / \mathrm{Si}$ ratios relative to Mongolia Gobi desert (Figure 3). The difference in the modal mineral abundance resulted in the spatial variability in the iron content (Figure 3). The sample MG04 from Mongolia Gobi desert has the lowest value (0.14\%), while the sample BJ06 in the Badain Jaran desert has the highest value (2.24\%) among all samples.

The analyzed 40,000 particles were grouped

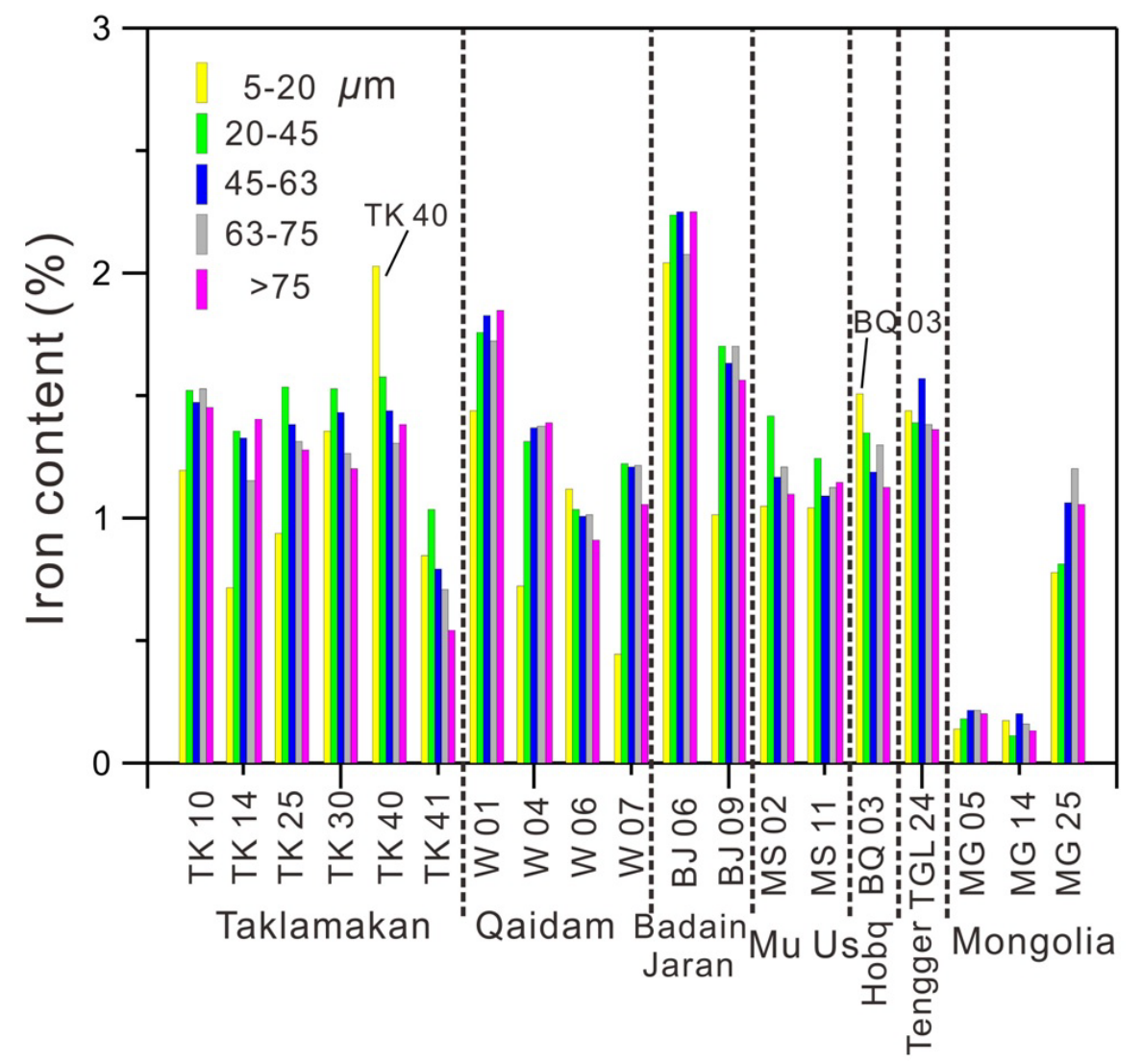

Figure 3: Iron content variations of different particle sizes. Iron content for all five size fractions for each sample. The iron content varied within a small range for the different size fractions. In contrast, iron content variations for different locations/deserts are more evident. A total of 19 samples from the source regions were analyzed, and represent the Taklamakan Desert (green), the Qaidam Desert (purple), the Badain Jaran Desert (orange), the Mu Us Desert (light blue), the Hobq Desert (red), the Tengger Desert (yellow) and the Mongolian Gobi (blue). 
into five size fractions, as 5-20 $\mu \mathrm{m}, 20-45 \mu \mathrm{m}, 45-$ $63 \mu \mathrm{m}, 63-75 \mu \mathrm{m}$ and $>75 \mu \mathrm{m}$. The modal mineral abundances were used to calculate separately the iron content for each size fraction. Our results show that in most of the samples, iron content in the fine-sized fraction $(5-20 \mu \mathrm{m})$ tended to be lower than the coarse-sized fractions $(20-75 \mu \mathrm{m}$ ) (Figure 3), with two excepted cases (samples TK40 and BQ03). Most likely, these observations suggest that the size reduction during the transport tends to decrease the iron contents derived from the source regions by abrasion loss of the iron phases.

\section{Discussion}

\section{Lithological origin of the iron phases in the dust sources}

All the minerals in the studied desert soil sam-
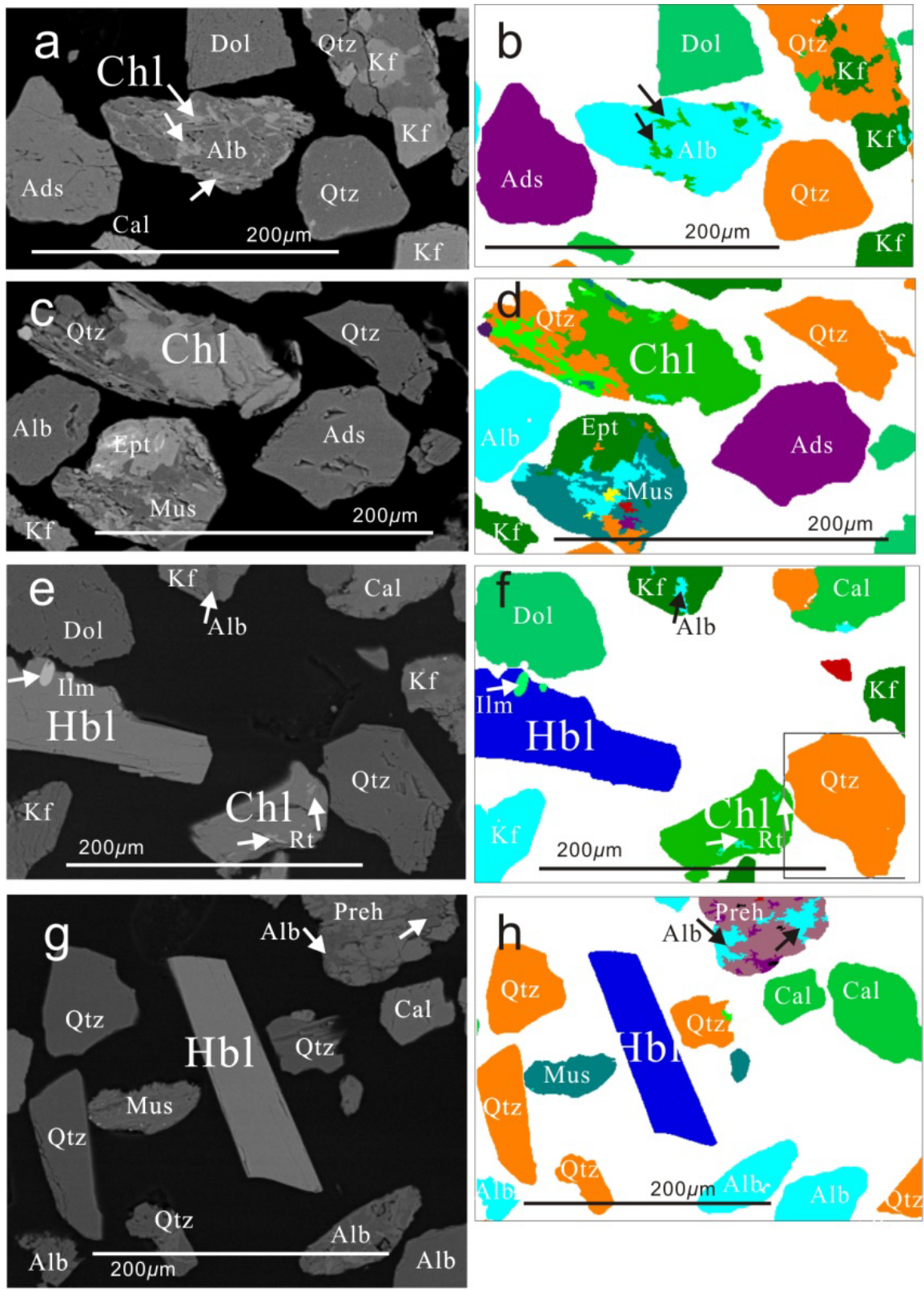

Figure 4: Micromorphology of chlorite and hornblende particles. Abbreviations: Ads = Andesine; Alb = Albite; $\mathrm{Cal}=$ Calcite $\mathrm{Chl}=$ Chlorite Dol = Dolomite; $\mathrm{Ept}=$ Epidote $\mathrm{Hbl}=$ Hornblende; $\mathrm{Ilm}=$ Ilmentite; $\mathrm{Kf}=\mathrm{K}$-feldspar; Mus = Muscovite; Preh = Prehnite; Qtz = Quartz and Rt $=$ Rutile. Back scatter electron (BSE) images and MLA mapping pictures of chlorite and hornblende particles have shown that chlorite (Chl) exists in several forms: Unshaped, fine-grained minor components ( $\mathbf{a}$ and $\mathbf{b}$ ); major grains ( $\mathbf{c}$ and $\mathbf{d}$ ) inside one large particle. $\mathbf{e}$ and f. BSE image and MLA picture for a hornblende ( $\mathrm{Hbl}$ ) particle. Hornblende was found as a complex particle crystallized with minor ilmentite $(\mathrm{Ilm}) . \mathbf{g}$ and $\mathbf{h}$. Morphology of a single mineral particle of hornblende. 
ples occur as single-particles and as multi-grain particles (rock fragments) (Figure 4). The textural information they record is readily related to the source rock [31], compared to the information obtained alone via the single-particles. We have collected the SEM images of the targeting iron-phases e.g. chlorite and hornblende. We observed that the desert soil consist of angular, sub-angular, and sub-rounded particles, which are randomly oriented and tightly aggregated (Figure 4). The width of the particle in general is over $20 \mu \mathrm{m}$, and the length of the largest particle shown in Figure 4 is $180 \mu \mathrm{m}$.

The largest particle in Figure 4 appears to occur as angular hornblende particle (Figure $4 \mathrm{~g}$ ). The angular shape revealed a very short distance of transport; thus, signal the "local origin". The shape parameters $(50 \mu \mathrm{m} \times 180 \mu \mathrm{m})$ indicate a derivation from coarse-grained bedrock e.g. granitic rock and high-grade metamorphic rock. The molten of Fe element inside the hornblende particle was observed in another angular particle of hornblende (Figure $4 \mathrm{e})$. The molten components of Fe occur as the ilmenite mineral phase, indicating a signature of very high Fe concentration (14\%) in hornblende [30]. The molten characteristics support that the coarsegrained hornblende particle originated from granitic rock and high-grade metamorphic rock [32].

Chlorite occurs in a diverse variety of rock fragments. (1) The clearly rod-like chlorite grains showed common intergrowth with albite in one sub-rounded particle (Figure 4a). The intergrowth characteristic with albite revealed that low-grade metamorphism resulted in this form. Chlorite also coexists with quartz in sub-angular particle (Figure 4c). (2) The quartz-chlorite particle (Figure 4c) is considered to form by sedimentary diagenesis of siliciclastic rocks, because the quartz show randomly oriented and abundant pores. (3) As angular single particle, chlorite is observed with dispersed accessory minerals e.g. titanium oxide in the particle (Figure 4e). With increasing metamorphism, titanium concentration seems to be excess in the chlorite grain [33]. Chlorite grain therefore undergoes titanium elemental migration out.

\section{Iron linked to uplifted mountains in the Asian inland}

Chlorite and hornblende incorporate medium-size cations, primarily $\mathrm{Fe}$ and $\mathrm{Mg}$, and commonly constitute low-grade metamorphic rocks [33].
The octahedral sites for high concentrations of Fe (II), determined by regional metamorphism, revealed that the large-scale mountain uplift strongly [34] affects the samples iron chemistry (Fe/Si ratio).

In contrast, the dust source on Mongolia Gobi is largely from the flat and still erosion Mongolia Plateau surface [35]. Wind erosion on the gravel produced a significant emission of dust from the Mongolian Gobi [36]. From our observation from different size fractions (Figure 3), wind erosion resulted in an increase the fine-sized particles that tended to decrease iron phases concentrations because of abrasion.

Here we find that the Fe (II)-bearing silicate minerals e.g. chlorite and hornblende [37], composed over $1 / 2$ of the iron content in all the six Chinese deserts, located along the high mountains in NTP. The northern uplifted edge of NTP contains many Paleozoic high-grade and low-grade metamorphic rocks [38]. The abundances of chlorite and hornblende found here (Figure 4) may arise from two types metamorphic rocks, tightly linked to the mountain uplift in NTP.

These mountains e.g. Qilian Mountain and Kunlun Mountain (Figure 1) have presently exceeded an altitude of $4000 \mathrm{~m}$ and steep slopes, resulting in high erosion rate and significant increase in sediments accumulated in lower deserts basins [39]. Owing to hyper aridity $(<100 \mathrm{~mm} / \mathrm{yr}$ in mean annual rainfall), this desert belt (roughly $35^{\circ} \mathrm{N}$ ) is in a limited chemical weathering environment [8] where fluvial and glacial transport are dominant erosive processes. Desert sand is periodically rejuvenated by the input of mountain erosion product [40].

\section{Connections with the atmospheric iron influx}

Dust from the Chinese deserts is prone to the long-distance transport (Figure 1). The observations of high chlorite concentration (3-5\%) in Asian dust along the transport pathway are reported in terrestrial [41] and the marine environment [42]. Hornblende occurrence is also observed in the downwind areas e.g. the Loess Plateau and the Korean peninsula [31]. The Chinese deserts sourced dust crosses the Pacific in the spring storms [4346], resulting in significant atmospheric iron influx over large sea areas. Mineral dust consist of particles that are lifted into the high atmosphere [47] when high speed winds as westerly jet occur over 
erodible surfaces of the deserts in the arid region (Figure 1).

Iron is a limiting and essential micronutrient for phytoplankton growth. The iron content in iron mineral phases plays an important role in the marine biochemical processes. Atmospheric supply of iron-bearing dust may stimulate primary productivity for ocean area, affecting biological carbon export [48] and causing a decrease in ocean surface $\mathrm{pCO}_{2}$ that was balanced by a drawdown of $\mathrm{CO}_{2}$ from the atmosphere [49]. However, the atmospheric iron influx that derived from Chinese deserts remains not clear.

To evaluate the contribution of the Chinese deserts to the atmospheric iron influx, the following parameters were taken as the essential reference. Firstly, dust emission account for $400 \mathrm{Tg}$ per year that are deposited in North Pacific [50]. Secondly, the fine-sized $(5-20 \mu \mathrm{m})$ particles originates from the large-sized particles $(20-75 \mu \mathrm{m})$ [51]. The size reduction during the transport tends to decrease the concentration of iron phases derived from the source regions. Thus the iron contents in the dust source deserts provide an upper limit estimate for the atmospheric iron influx. Thirdly, according to previous study of dust emission [24,25] the amount of dust emission flux shows spatial variations. The dust emission flux data in each of the Chinese deserts and the Mongolian Gobi are listed in Supplementary Table $2 \mathrm{~S}$. Combine with the data of iron content in each of the dust sourced deserts (Table $2 \mathrm{~S})$, the weight-averaged dust iron influx ranges from 2.14 to $5.69 \mathrm{Tg}$ per year.

Previous studies suggest that the soluble iron deposited in the global oceans range between 0.36 and $1.6 \mathrm{Tg}$ per year [52]. That means the iron soluble in North Pacific is potentially much lower than the total iron influx over the ocean. Large uncertainty exists in the estimates because the iron solubility in the desert dust has been lack. There has barely been any study on the spatial-temporal variations of iron solubility worldwide, except for cases reported regionally. Recent studies suggest that the iron solubility is largely determined by amorphous iron oxide (ferrihydrite) [5,53]. It is hypothesized that ferrihydrite phases are secondary in origin, based on the observation that natural weathering process in tropical and sub-tropical soils increases its formation. Unfortunately, the dust sources in Chinese deserts have very low precipitations and soil moisture [8]. Nonetheless, during the long-distance transport, particles as chlorite, hornblende, etc. may have been altered and therefore increase the formation of ferrihydrite phases $[4,54,55]$. Future study may focus on chemical weathering and the release of bio-available iron from natural dust particles (chlorite, hornblende etc.) that will be benefit to the simulating models for global dust emission.

\section{Conclusion}

The iron hosted phases in the Chinese deserts is predominant in all of the 38 minerals. The dominant iron phases are chlorite and hornblende that contribute $50-60 \%$ iron content in the Chinese deserts. Rock fragment identification suggests that the particles containing chlorite and hornblende are most likely sourced from the low- and high-grade metamorphic rock that located along the Northern Tibetan Plateau. The mountain belts supply a particularly erodible dust source as the ultimate provenance of iron. Dusts from such provenance are disproportionately important for remote transport of aerosols.

We also detected that dust may not preserve the initial iron mineralogy originated from the deserts. The iron content essentially changed during the transport and particularly has decreased in the fine-sized fraction (5-20 $\mu \mathrm{m})$ than the coarse-sized fractions (from 20 to $75 \mu \mathrm{m}$ ) due to the abrasion loss of iron phases.

On the basis of iron contents and the data of dust emission flux, we estimated that the atmospheric iron influx from Chinese deserts range from $2.14 \mathrm{Tg}$ per year to $5.69 \mathrm{Tg}$ per year. Due to the loss of iron phases during the transport, our study provides an upper-limit estimate for the atmospheric iron influx. Compared with the estimates of soluble iron flux (0.36-1.6 Tg per year) in global oceans, iron solubility is highly suggested for the interpretation for this large difference between different estimates. This makes concluding what process in the atmosphere difficult to convert iron to soluble iron.

\section{Acknowledgement}

This study was funded by the National Science Foundation of China (Grant nos. 41877284).

\section{References}

1. Jickells TD, An ZS, Andersen KK, Baker AR, Bergamet- 
ti G, et al. (2005) Global iron connections between desert dust, ocean biogeochemistry, and climate. Science 308: 67-71.

2. Mahowald NM, Engelstaedter S, Luo C, Sealy A, Artaxo $P$, et al. (2008) Atmospheric iron deposition: Global distribution, variability, and human perturbations. Ann Rev Mar Sci 1: 245-278.

3. Lafon S, Rajot JL, Alfaro SC, Gaudichet A (2004) Quantification of iron oxides in desert aerosol. Atmospheric Environment 38: 1211-1218.

4. Zongbo Shi, Michael D Krom, Steeve Bonneville, Alex R Baker, Timothy D Jickells, et al. (2009) Formation of iron nanoparticles and increase in iron reactivity in mineral dust during simulated cloud processing. Environ Sci Technol 43: 6592-6596.

5. Schroth AW, Crusius J, Sholkovitz ER, Bostick BC (2009) Iron solubility driven by speciation in dust sources to the ocean. Nature Geoscience 2: 337-340.

6. Journet E, Desboeufs KV, Caquineau S, Colin J-L (2008) Mineralogy as a critical factor of dust iron solubility. Geophysical Research Letters 35: 75-86.

7. Takahashi $\mathrm{Y}$, Higashi M, Furukawa T, Mitsunobu $S$ (2011) Change of iron species and iron solubility in Asian dust during the long-range transport from western China to Japan. Atmos Chem Phys 11: 11237-11252.

8. Wanyi Lu, Wancang Zhao, William Balsam, Huayu Lu, Pan Liu, et al. (2017) Iron Mineralogy and Speciation in Clay-Sized Fractions of Chinese Desert Sediments. J Geophys Res-Atmos 122: 13458-13471.

9. Junfeng Ji, Jun Chen, William Balsam, Huayu Lu, Youbin Sun, et al. (2004) High resolution hematite/ goethite records from Chinese loess sequences for the last glacial-interglacial cycle: Rapid climatic response of the East Asian Monsoon to the tropical Pacific. Geophysical Research Letters 31: 347-348.

10.Maher BA, Prospero JM, Mackiec D, Gaiero D, Hessee PP, et al. (2010) Global connections between aeolian dust, climate and ocean biogeochemistry at the present day and at the last glacial maximum. Earth-Science Reviews 99: 61-97.

11.Shao Y (2001) A model for mineral dust emission. J Geophys Res-Atmos 106: 20239-20254.

12.Jun Chen, Gaojun Li, Jiedong Yang, Wenbo Rao, Huayu Lu, et al. (2007) Nd and Sr isotopic characteristics of Chinese deserts: Implications for the provenances of Asian dust. Geochimica et Cosmochimica Acta 71: 3904-3914.

13.Hu FG, Yang XP (2016) Geochemical and geomor- phological evidence for the provenance of aeolian deposits in the Badain Jaran Desert, northwestern China. Quaternary Sci Rev 131: 179-192.

14.Junsheng Nie, Thomas Stevens, Martin Rittner, Daniel Stockli, Eduardo Garzanti, et al. (2015) Loess Plateau storage of Northeastern Tibetan Plateau-derived yellow river sediment. Nat Commun 6.

15.Sun JM (2005) Nd and Sr isotopic variations in Chinese eolian deposits during the past $8 \mathrm{Ma}$ : Implications for provenance change. Earth Planet Sc Lett 240: 454-466.

16.Yan Y, Sun Y, Chen H, Ma L (2014) Oxygen isotope signatures of quartz from major Asian dust sources: Implications for changes in the provenance of Chinese loess. Geochimica et Cosmochimica Acta 139: 399-410.

17.Derbyshire E, Meng X, Kemp RA (1998) Provenance, transport and characteristics of modern aeolian dust in western Gansu Province, China, and interpretation of the Quaternary loess record. Journal of Arid Environments 39: 497-516.

18.Sun J, Zhu R, An Z (2005) Tectonic uplift in the northern Tibetan Plateau since 13.7 Ma ago inferred from molasse deposits along the Altyn Tagh Fault. Earth Planet Sc Lett 235: 641-653.

19. Herman F, Seward D, Valla PG, Carter A, Kohn B, et al. (2013) Worldwide acceleration of mountain erosion under a cooling climate. Nature 504: 423-426.

20.Zhang P, Molnar P, Downs WR (2001) Increase sedimentation rates and grain sizes 2-4 Myr ago due to the influence of climate change on erosion rates. Nature 410: 891-897.

21. Formenti P, L Schutz, Balkanski Y, Desboeufs K, Ebert $M$, et al. (2011) Recent progress in understanding physical and chemical properties of African and Asian mineral dust. Atmos Chem Phys 11: 8231-8256.

22.Yang XP, Li HW, Conacher A (2012) Large-scale controls on the development of sand seas in Northern China. Quaternary International 250: 74-83.

23. Muhs DR (2004) Mineralogical maturity in dunefields of North America, Africa and Australia. Geomorphology 59: 247-269.

24.Zhang XY, Gong SL, Shen ZX, Mei XXXI, Liu LC, et al. (2003) Characterization of soil dust aerosol in China and its transport and distribution during 2001 ACEAsia: 1. Network observations. J Geophys Res-Atmos 108.

25.Zhang XY, Gong SL, Shen ZX, Mei FM, Xi XX, et al. (2003) Sources of Asian dust and role of climate 
change versus desertification in Asian dust emission. Geophysical Research Letters 30.

26.Sun JM, Ding ZL, Liu TS (1998) Desert distributions during the glacial maximum and climatic optimum: Example of China. Episodes 21: 28-31.

27.Yang XP, Rost KT, Lehmkuhl F, Zhenda Z, Dodson J (2004) The evolution of dry lands in northern China and in the Republic of Mongolia since the Last Glacial Maximum. Quaternary International 118: 69-85.

28. Mason JA, Lu H, Zhou Y, Miao X, Swinehart B, et al. (2009) Dune mobility and aridity at the desert margin of northern China at a time of peak monsoon strength. Geology 37: 947-950.

29.Gu Y, Schouwstra RP, Rule C (2014) The value of automated mineralogy. Minerals Engineering 58: 100103.

30.Deer WA, Howie RA, Zussman J (1997) Rock-forming minerals. $\left(2^{\text {nd }} e d n\right)$, The Geological Society, London.

31.Jeong GY, Hillier S, Kemp RA (2008) Quantitative bulk and single-particle mineralogy of a thick Chinese loess-paleosol section: implications for loess provenance and weathering. Quaternary Sci Rev 27: 12711287.

32.Raymond LA (2007) Petrology: The study of igneous, sedimentary, and metamorphic rocks. $\left(2^{\text {nd }}\right.$ edn), Waveland Pr Inc.

33. Wybrecht E, Duplay J, Pique A, Weber F (1985) Mineralogical and chemical evolution of white micas and chlorites, from diagenesis to low-grade metamorphism - data from various size fractions of greywackes (Middle-Cambrian, Morocco). Mineral Mag 49: 401-411.

34.Jolivet M, Brune M, Seward D, Xu Z, Yang J, et al. (2001) Mesozoic and Cenozoic tectonics of the northern edge of the Tibetan plateau: Fission-track constraints. Tectonophysics 343: 111-134.

35. Marc Jolivet, Jean-François Ritz, Riccardo Vassallo, Christophe Larroque, Régis Braucher, et al. (2001) Mongolian summits: An uplifted, flat, old but still preserved erosion surface. Geology 35: 871.

36. Rivka Amit, Yehouda Enzel, Amit Mushkin, Alan Gillespie, Jigjidsurengiin Batbaatar, et al. (2014) Linking coarse silt production in Asian sand deserts and Quaternary accretion of the Chinese Loess Plateau. Geology 42: 23-26.

37.Plissart $G$, Féménias $O$, Mãruntiu $M$, Diot $H$, Demaiffe $D$ (2009) Mineralogy and geothermometry of gabbro-derived listvenites in the Tisovita-luti Ophiolite, Southwestern Romania. The Canadian Mineralogist 47: 81-105.
38.Ji JF, Chen J, Lu HY (1999) Origin of illite in the loess from the Luochuan area, Loess Plateau, Central China. Clay Minerals 34: 525-532.

39.Montgomery DR, Brandon MT (2002) Topographic controls on erosion rates in tectonically active mountain ranges. Earth Planet Sc Lett 201: 481-489.

40.Zhu B, Yang X (2009) Chemical weathering of detrital sediments in the Taklamakan desert, Northwestern China. Geographical Research 47: 57-70.

41.Tong He, Lianwen Liu, Yang Chen, Xuefen Sheng, Junfeng Ji, et al. (2018) Glacial-interglacial change in chlorite concentration from the Lingtai section in the Chinese Loess Plateau over the past 1.2 Ma and its possible forcing mechanisms. Quaternary Res 89: 511-519.

42. Blank M, Leinen M, Prospero JM (1985) Major Asian aeolian inputs indicated by the mineralogy of aerosols and sediments in the Western North Pacific. Nature 314: 84-86.

43. Rea DK (1994) The paleoclimatic record provided by eolian deposition in the deep-sea - the geologic history of wind. Reviews of Geophysics 32: 159-195.

44.David K Rea, Lucy W Chambers, John M Chuey, Thomas R Janecek, Margaret Leinen, et al. (1986) A 420,000 -year record of cyclicity in oceanic and atmospheric processes from the eastern equatorial pacific. Paleoceanography 1: 577-586.

45. Rea DK, Hovan SA (1995) Grain-size distribution and depositional processes of the mineral component of abyssal sediments - lessons from the north pacific. Paleoceanography and Paleoclimatology 10: 251258.

46. Rea DK, Leinen M, Janecek TR (1985) Geologic approach to the long-term history of atmospheric circulation. Science 227: 721-725.

47.Jeong GY, Kim JY, Seo J, Kim GM, Jin HC, et al. (2014) Long-range transport of giant particles in Asian dust identified by physical, mineralogical, and meteorological analysis. Atmos Chem Phys 14: 505-521.

48. Moore JK, Braucher O (2008) Sedimentary and mineral dust sources of dissolved iron to the world ocean. Biogeosciences Discussions 5: 631-656.

49. Martin JH (1990) Glacial-interglacial $\mathrm{CO}_{2}$ change: The iron hypothesis. Paleoceanography and Paleoclimatology 5: 1-13.

50.GESAMP (1989) The atmospheric input of trace species to the world ocean. WorldMeteorological Organization.

51.Pye K (1989) Paleoclimatology and paleometeorolo- 
gy: Modern and past patterns of global atmospheric transport. In: Margaret Leinen, Michael Sarnthein, NATO ASI Series, Springer, Netherlands, 1: 3-30.

52. Chao Luo, Mahowald NM, Meskhidze N, Chen Y, Siefert RL, et al. (2005) Estimation of iron solubility from observations and a global aerosol model. Journal of Geophysical Research: Atmospheres 110: 33453356.

53. Michel FM, Ehm L, Antao SM, Lee PL, Chupas PJ, et al. (2007) The structure of ferrihydrite, a nanocrystalline material. Science 316: 1726-1729.

54.Shi Z, Krom MD, Bonneville S, Benning LG (2015)
Atmospheric processing outside clouds increases soluble iron in mineral dust. Environ Sci Technol 49: 1472-1477.

55.Jeong GY (2008) Bulk and single-particle mineralogy of Asian dust and a comparison with its source soils. J Geophys Res-Atmos 113.

56.Sun JM, Zhang MY, Liu TS (2001) Spatial and temporal characteristics of dust storms in China and its surrounding regions, 1960-1999: Relations to source area and climate. Journal of Geophysical Research-Atmospheres 106: 10325-10333.

57.NASA (2013) A portrait of global winds. 
Table 1S: Geographical locations of desert samples.

\begin{tabular}{|c|c|c|c|c|c|}
\hline Desert & SID & Latitude/ ${ }^{\circ}$ & Longitude/ ${ }^{\circ}$ & Landscape & Dunes \\
\hline \multirow{6}{*}{ Taklamakan } & TK10 & 38.23 & 85.35 & sand sea & mobile \\
\hline & TK14 & 37.18 & 82.85 & sand sea & mobile \\
\hline & TK25 & 41.11 & 82.43 & sand sea & mobile \\
\hline & TK30 & 38.61 & 80.97 & sand sea & mobile \\
\hline & TK40 & 39.46 & 78.09 & sand sea & mobile \\
\hline & TK41 & 39.92 & 78.47 & sand sea & mobile \\
\hline \multirow{4}{*}{ Qaidam } & W01 & 37.90 & 91.84 & sandy land & immobile \\
\hline & W04 & 36.03 & 97.78 & sandy land & immobile \\
\hline & W06 & 36.46 & 94.37 & sandy land & immobile \\
\hline & W07 & 37.36 & 95.49 & sandy land & immobile \\
\hline \multirow{2}{*}{ Badain Jaran } & BJ06 & 42.02 & 101.58 & sand sea & mobile \\
\hline & BJ09 & 40.93 & 100.63 & sand sea & mobile \\
\hline \multirow{2}{*}{ Mu Us } & MSO2 & 37.82 & 107.40 & sandy land & immobile \\
\hline & MS11 & 38.79 & 106.73 & sandy land & immobile \\
\hline Hobq & BQ03 & 40.45 & 109.61 & sand sea & mobile \\
\hline Tengger & TGL24 & 38.94 & 103.36 & sand sea & mobile \\
\hline \multirow{3}{*}{ Mongolian gobi } & MG05 & 44.48 & 110.03 & gobi gravel & - \\
\hline & MG14 & 43.31 & 105.87 & gobi gravel & - \\
\hline & MG25 & 44.62 & 102.38 & gobi gravel & - \\
\hline
\end{tabular}

Table 2S: Dust emission amount and the iron concentrations in siliceous minerals from dust source deserts.

\begin{tabular}{|l|l|l|l|l|l|}
\hline \multirow{2}{*}{ Desert } & Number of samples & Fe (\%) & \multirow{2}{*}{ Dust production (\%) } & \multicolumn{2}{|l|}{ Iron influx (Tg*yr-1) } \\
\cline { 6 - 7 } & in silicate & & Lower limit & Upper limit \\
\hline Taklimakan & 6 & $0.64-1.67$ & 21 & 0.54 & 1.40 \\
\hline Qaidam & 4 & $0.92-1.83$ & 5 & 0.18 & 0.37 \\
\hline Badain Jaran & 2 & $1.58-2.24$ & 22 & 1.01 & 2.51 \\
\hline Tengger & 1 & 1.37 & - & - & - \\
\hline Mu Us & 2 & $1.12-1.15$ & 4 & 0.18 & 0.18 \\
\hline Hobq & 1 & 1.15 & - & - & - \\
\hline Mongolian gobi & 3 & $0.2-1.06$ & 29 & 0.23 & 1.23 \\
\hline Total & 19 & & & 2.14 & 5.69 \\
\hline
\end{tabular}

*Dust production percentages are not available for the Tengger and Hobq deserts. 